\title{
The Road Taken: Origins and Evolution of Employment Systems in Emerging Companies
}

\author{
James N. Baron, M. Diane Burton and \\ MICHAEL T. HANNAN
}

(Graduare School of Business, Scanford University, Scanford, CA, USA)

Drawing on a unique arcbive of qualitative and quantitative data describing 100 Bay Area bigh tecbnology firms witbin their first decade, this paper acamines sthe madels of amployment relations aspoused by company founders and bow tbase models sbaped the avolution of buman resounce management witbin their organizations. Information gleaned from intervious suggests that founders and otbers involved in designing and lasucbing tbese companies bad blupprints for the employment relation that varied along three bey dimensions: the primany basis of employee attacbment and motivation, the primary means for controlling and coordinating work, and tbe primary oriterion emplasizad in selection. Based on combinations of these tbree dimensions, firms in our sample cluster fall into one of four distinct types, wbicb we Label the star, factory, enginearing, and commitment madels. Multivariate statistical analyses document bow sbe founder's employment model shaped tbe subsequent adoption and timing of various bemen resoura policies and documents our tbese companies' early bistories, as well as the speed witb wbich tbe first full-time besman nesource manager was appointed. The findings are strongly suggestive of complementarities and a tendency toward internal consistency among dimensions of buman nesource menagement, and of strong patb dependence in tbe avolution of employment systems in organizations. Some implications of these findings for trensactions cast perspectives on the amployment nelationsbip are discoussed.

\section{Introduction}

A central concern of transaction cost economics (TCE) has been to understand how employment relationships and governance structures develop around productive activities. Williamson's (1975) operating hypothesis has 
been that organizational forms and employment systems develop'so as to minimize the transaction costs and hold-up problems facing employers and employees. These issues arise primarily from relationship-specific skills and investments (and the small numbers bargaining they induce ex past), task interdependencies, opportunism and informational imperfections that make spot contracting or contingent claims contracting infeasible or very costly. In more recent work, Williamson (1992) has acknowledged the prevalence of organizational inertia and path-dependent development, which have been documented in the empirical literanure on organizations (Barnert and Carroll, 1995). However, he argues that inertia and path dependence likely reflect either an absence of strong competitive pressures (the scope conditions under which the hypothesis of transaction cost minimization is most intended to apply) or a situation in which the adjustment costs of getting to 'first best' exceed the anticipated incremental gains.

Williamsonian reasoning has stimulated the development of typologies of organizational employment systems. Spot contracting through markets is thought to be optimal when work is independent and easy to monitor, when the skills involved are general, and when, accordingly, employees or employers have little room for opportunism. When the parties cannot contract ax ante for what is to be done or circumvent problems that arise from small numbers and/or monopoly power, markets fail. Then bureaucracies are preferable, because they bind the interests of both employer and employee through long-term relationships and rely on rules and monitoring devices to discourage opportunism (Williamson, 1975, 1981). When casks are extremely interdependent and/or difficult to monitor, team or 'clan' employment systems relying more on cultural controls (peer monitoring and internalization of values) are superior (Ouchi, 1980). Some extant empirical evidence supports the notion that the design of human resource systems and the management of employment relationships in organizations is broadly consistent with these predictions of transactions cost economics (Pfeffer and Cohen, 1984; Baron at al., 1986; Cohen and Pfeffer, 1986).

However, several ambiguities complicate the process of subjecting TCE to rigorous empirical test. One applies to any approach that, like TCE, emphasizes companative statics. It concerns the time-frame over which transaction cost minimization is expected to occur. Indeed, if an organization exists in a scable equilibrium or can continually adjust its employment practices in response to changes in its external environment and internal constrnints, then matters are rather straightforward. However; it seems quite likely that organization employment systems are chanacterized by considerable path dependence. Hannan and Freeman $(1977,1984)$ argued that inertial tendencies in organizations are most acute in the 'core' of organizations, where the 
benefits of reproducibility and legitimacy are greatest and where, because of interdependencies, even a minor change has potentially enormous ramifications for other parts of the organization. For reasons that are outlined in our companion paper (Hannan et al., 1996), altering the premises of employees' relationships with the organization, as well as the specific HR practices that undergird those relationships, is likely to be extraordinarily contentious, which might explain the oft-noted difficulty of achieving large-scale change in HR systems (Pfeffer, 1994). Indeed, from an economic theory standpoint, a critical objective in structuring employment relationships is establishing a repucation, vis-d-vis current and prospective employees (Simon, 1951; Kreps, 1996). There might be an inherent tension between developing and maintaining a strong reputation among employees in the labor market, which is predicated on continuity and stability in employment practices, and continually realigning the organization's HR activities in lighe of changing internal and external circumstances.

In this paper, we wish to focus on a second ambiguity that complicates efforts to test the implications of TCE reasoning for employment relationships. It concerns the level of analysis at which transaction-cost minimization should be expected to occur. Evidence of transaction cost economizing will be easier to discern when organizations manage a set of completely separable (i.e. non-interdependent) activities, which can each be structured and controlled through a distinctive combination of employment policies and practices, than when there are strong technological, normative, or other interdependencies among activities that necessitate common policies across disparate tasks and labor forces. Moreover, if there are inherent complementarities among sets of human resource practices, then organizational designers might have limited ability to pick and choose among specific policies in structuring employment relations and governance practices. Instead, they might have to select from among a limited number of human resource 'systems' that represent menus or clusters of human resource practices.

Similarly, there may be what (Williamson, 1975) terms 'atmospheric' benefits associated with organizing a whole menu of activities through a common set of organizational procedures and routines (e.g. a single organizational culture or set of employment practices). For instance, structuring pay, promotion and other employment practices very differently across diverse occupations or departments within an organization, even if seemingly warranted based on human capital or other considerations, might generate so much counterproductive dissent internally or illegitimacy externally as to outweigh the benefits. Accordingly, a consistent set of employment practices that might appear suboptimal for each of a set of activities might be optimal (or nearly so) for the organization as a whole. 
Baron and Kreps (in press) suggest at least three reasons to expect employment practices within organizations to cluster into consistent bundles. First, as Milgrom and Roberts (1995) note in discussing the Lincoln Electric Company, there are some obvious technical complementarities among particular HR practices. For instance a start-up firm intending to invest heavily in training its workers will benefit disproportionately from carefully screening applicants and from adopting practices to reduce turnover. Conversely, companies having screened carefully and/or implemented turnover-reduction mechanisms are likely to benefit disproportionately from investments in training employees.

A second reason for expecting consistency involves the psychology of perception and cognition. Psychological theory and research indicate that messages are more salient and recalled better when the multiple stimuli being transmitted are simple and support the same message. Internal consistency, which also entails simplicity (i.e. everything follows the same basic principles), should aid employees in learning about what is expected of them and what they can expect in turn. This is also likely to offer several benefits to the employer, including: superior matching or sorting between potential employees and the job opportunities offered by the firm; reduced need for monitoring employees' activities or clarifying ambiguous or contradictory expectations; and greater ability to provide long-term incentives and career development because employees clearly understand what is expected and valued.

Baron and Kreps (in press) suggest a third category of reasons for expecting consistency in HR practices: social forces. External consistency-that is, congruence between a firm's employment system and external social norms and preconceptions-presumably facilitates learning. Both parties to the employment relation are likely to find it casier to comprehend the nature of the relationship when its employment practices consistently (and symbolically) mimic previously-internalized codes of conduct from other contexts, whether these patterns are akin to an anonymous marketplace (dog-eat-dog) or a family relationship (mutual caring). By this logic, for instance, it would be difficult for a set of founders who shared strong kinship or long-standing friendship bonds to establish a company whose personnel policies reflected either a Draconian or an arms-length posture vis-ad-vis employees. Similarly, personnel policies that encourage employees to identify themselves as members of a corporate 'family' (long-term employment, open door policies, suggestion systems, etc.) would not seem to-mesh well with other practices that convey the message that employees are interchangeable, expendable, or simply a cost that the firm must bear.

According to Baron and Kreps, the same arguments regarding consistency 
among HR practices also apply to the issue of how differentiation or inconsistency in treatment among subgroups within an organization will affect transaction costs. They note that pressures toward uniform treatment are likely to be especially acute in organizations with: (a) high technical interdependence; (b) a labor force that is socially and demographically homogeneous; (c) a strong unified 'culture'; (d) an internal labor market and/or extensive job rotation and lateral transferring; and (e) a broader social environment that does not legitimate differential treatment among segments of the labor force or the society (also see Baron and Pfeffer, 1994).

These arguments regarding consistency in human resource management posit various benefits to employers and/or employees from organizing employment relationships around consistent $H R$ premises and practices and by drawing on models of social relationships from other settings. If correct, these arguments imply that, over time, some advantages in terms of performance or survival should accrue to organizations whose employment relationships are internally consistent and/or structured to mimic other social systems with which their employees have experience. However, another explanation for why we might expect to observe consistency in HR systems is less instrumental and more cognitive-namely, it may be difficult for individuals, including those who design and manage organizations, to espouse and enforce contradictory principles. Robert Frank (1988), among others, has noted some important economic consequences of the psychological tendency toward cognitive consistency, both in the beliefs we hold and in the codes of behavior we bring to different economic transactions. According to his argument, an employer wishing to develop a reputation for trustworthiness with suppliers and customers, for instance, will find this harder to do unless she consistently acts in a benevolent and trustworthy fashion (e.g. in dealing with other constituencies, such as employees). Similarly, psychological theories of consistency suggest that it creates cognitive strain to espouse discrepant beliefs, such as the view that employees are good, knowledgeable and trustworthy alongside the view that they require close monitoring and powerful incentives to be motivated to comply with the firm's objectives. This line of reasoning suggests that consistency among HR practices and between employment relations and other types of social relations-may simply reflect a basic psychological tendency but not necessarily entail any implications for economic performance.

This brief overview suggests several potentially useful foci for research on how employment relationships become established in the carly years of organizations. One concerns the degree of 'alignment' of the human resource policies and practices of organizations with their technologies and business strategies. Evidence on whether alignment is evident at the inception of 
firms, or instead seems to be achieved gradually over time, might speak to the time-frame over which entrepreneurs are seeking to minimize transaction costs. We take up this issue in our companion paper in this issue (Hannan at al., 1996). A second useful focus of research concerns the implications of 'complementarities' and the need for internal consistency-both among specific HR practices (e.g. recruitment, compensation, performance evaluation, training, job design, etc.) and in the treatment of different segments of the work-force-for the design of human resource systems. To the extent that there are complementarities among specific HR practices and interdependencies (of a technical or social character) among segments of an organization's work-force, the problem of selecting and implementing the optimal governance regime might be more complicated than a stylized TCE story would imply. It is this issue that is explored in this paper.

There has been much more writing about the prevalence and virtues of internal consistency in HR systems than careful empirical study of the matter. There are a few noteworthy exceptions to this generalization. For instance, MacDuffie's (1995) work on the worldwide automobile industry documents a tendency for firms employing so-called high commitment work systems to avail themselves of an interrelated bundle of $H R$ practices. An interesting longitudinal study of production lines in the steel industry (Ichniowski at al., 1993) shows that productivity was enhanced by adopting various HR innovations that are generally associated with high commitment work systems, but that the returns to adopting a given practice were enhanced when other elements of a high commitment work system were either adopted simultaneously or already in place within the establishment.

It should be obvious that these issues are difficult to study without knowing a great deal about how an organization evolves over time, particularly about key decisions and developments in the early years of a company that might have momentous consequences for how it evolves and performs over time. In other words, it is not clear whether meaningful theoretical inferences can be drawn from most empirical studies of employment systems in organizations, which tend to be either cross-sectional comparisons across a sample of fairly long-lived 'survivor' organizations or case studies of what has transpired in a particular setting. Most extant research on HR systems focuses on relatively mature and long-lived organizations in seeking to identify the nature and benefits of HR alignment and internal consistency. Yet if consistency among HR practices is important, and if organizational designers seek to capitalize (either intentionally or unintentionally) on models of social relationships drawn from other settings (other firms, the family, educational institutions, etc.), this should be particularly evident when organizations are assembling their employment systems in their early years. 
Specifically, we should be able to find evidence not only in what the architects of nascent organizations say about what they were trying to achieve and what models they had in mind, but also in how their organizations evolved in the early years-for instance, whether the development of particular HR practices corresponds to a clear organizational blueprint and exhibits a logic of internal consistency.

The difficulty of obtaining the requisite life history data on organizations, particularly information about their formative years, might help explain why these issues have not received more attention in prior empirical research addressing employment relationships and/or transaction cost economizing. This paper reports some of the preliminary research findings from the Stanford Project on Emerging Companies (SPEC), an ongoing large-scale study designed to gather precisely this kind of information about early organization-building activities. Our goals in this paper are more descriptive than explanatory; we exploit the rich information we have obtained on the process of organization-building from interviews with founders, chief executives and senior HR officials, which describe the timing of various crucial events in the process of creating the firm's governance systems and also the imagery and intentions of the firm's architects. We use this information to identify several distinct models for organizing employment and work that recur within our sample of high technology start-ups. By examining how these models are conceptualized, constructed and articulated in the early years of start-up firms, we gain some insight into how organizational designers approach the issue of consistency and complementarities in human resource management and the extent to which they are seeking to develop employment systems that transcend particular HR practices and occupations within the firm. In our companion paper in this volume (Hannan et al., 1996), we explore some of the determinants of founders' human resource models and document how those models profoundly influence subsequent organizational evolution.

\section{Brief Overview of SPEC}

To control for labor market and environmental conditions, we focus on firms in one region and a particular sector of economic activity: technology-oriented companies in California's Silicon Valley. The continuing flow of high tech start-ups in the Silicon Valley area provides many opportunities to collect information on the early history of interesting firms. One goal of this research is to understand how early decisions affect future outcomes, which necessitates information about the earliest days of the organization. We assumed that individuals could only reasonably recall fairly recent informa- 
tion; thus, we limited our study to firms that were no more than ten years of age at the time we asked them to participate in the project. A second project goal is to understand how human resource systems are established. We assumed that organizations need to be of a minimum size before facing a need for any formal systems of practices; accordingly, firms in our study needed to have at least ten employees when the study commenced (in 1994). To identify the population, we purchased extracts from two commercial databases on technology companies: Rich's Everyday Sales Prospecting Guide and CorpTecb. From these sources, we drew a stratified random sample of high technology firms with headquarters in Silicon Valley, oversampling young firms and large firms (Burton, 1995). The firms we targeted for study are concentrated in computer hardware and/or software, telecommunications (including networking equipment), medical/biological technologies and semiconductors. Foreign-owned firms were excluded from the population, as were operating units of other organizations, because we were concerned that the structures and practices of such enterprises would reflect broader influences whose effects we could not adequately control.

With these restrictions, we identified 676 firms that met our selection criteria as of spring 1994. We approached 250 of these firms; 100 agreed to participate in the study. ${ }^{1}$ Happily, there was little evidence of systematic bias in response to our request for participation (see below). Figure 1 reports the 'target' composition of firms sought through our stratified sampling plan, as well as the age and size distribution of firms in our sample.

\section{Data Collection}

Trained MBA and doctoral students conducted semi-structured interviews with the CEO and the key informants that s/he had nominated to provide information about company history and human resource practices. Informants about company history and human resource management were also asked to complete pencil and paper surveys and return them to us prior to being interviewed. (For detailed information on the data gathered in each firm, see Burton, 1995). These surveys solicited details about the firm and its history; this information was used to guide the interviews.

(i) Founders were asked to recount the details of the founding: how the founding team was assembled, the original business plan, the planned

\footnotetext{
1 During the summer of 1995, evernl hundred mone frms were invited to participace in SPEC, and to dace en additional 72 firms beve agreed to do as, bringing the tool ample up to 172 companies. The fost 100 companies, which were sudied during che summer of 1994, will be revisited in the summer of 1996 to update their buman rescurce activities, organiational performance and ocher leg information.
} 


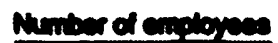

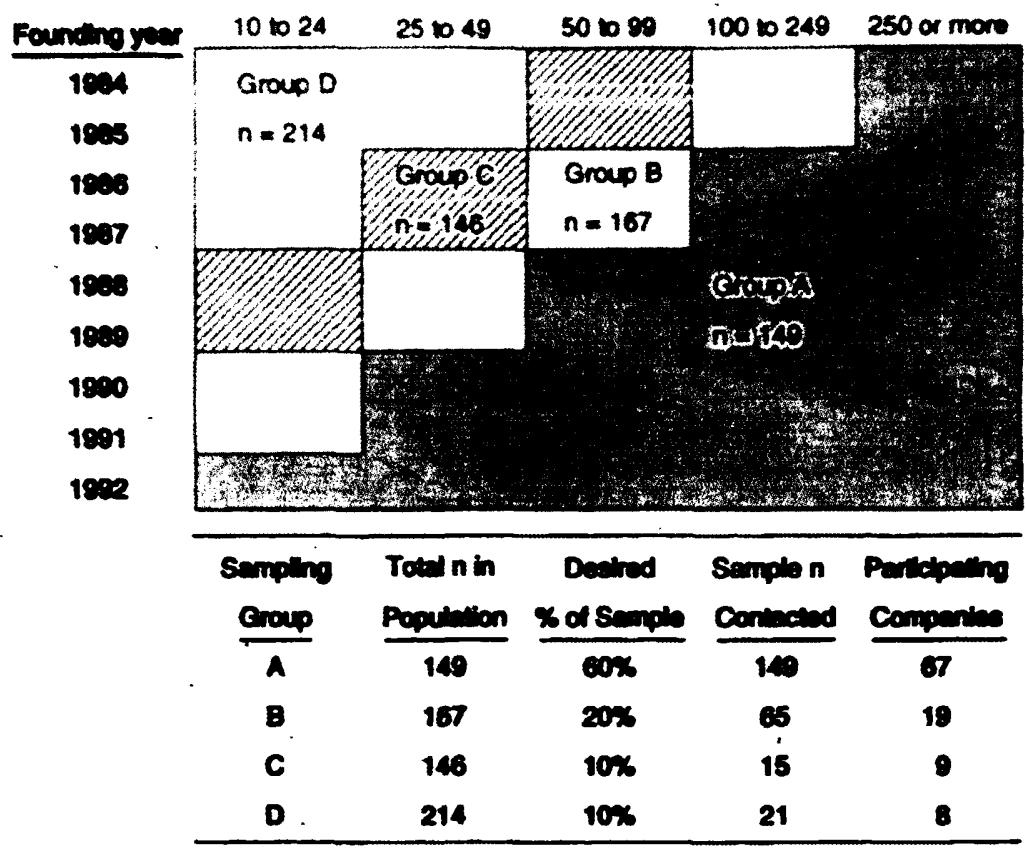

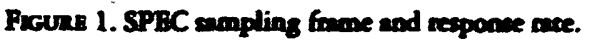

core competencies of the firm, sources of initial capital, initial steffing and initial employment practices. They were queried about their own professional background, external partners and stakeholders and whecher there was a clear organizational 'vision' or blucprint in creating the enterprise (and, if so, where it came from). Founders were also asked to report on the firm's current structure and practices and to identify the timing and nature of major organizational changes or 'milestones'. Pounder interviews typically lasted 60 minutes. Nlthough interviewers were given a template and set of probes for these interviews, the interviews tended to follow a direction set by the founder.

(ii) Following a similar semi-structured incerview format, CEOs were saked to provide detailed information on the firm's current stracegy. structure, business enviroament and mangement challenges. These froe-ta-fice interviews typically bered 45 minutes.

(iii) Senior mangers with responsibility for human resources were asked to provide extensive information abour the firm's past and current employment prectices. Human resources interviews typically lested 90 minuces. 
TABLE 1. Age and size distribution for SPEC participaring companies

\begin{tabular}{|c|c|c|c|c|c|c|}
\hline Founding Year & $\begin{array}{l}\text { Number } \\
10 \text { to } 24\end{array}$ & $\begin{array}{l}\text { femployee } \\
25 \text { to } 49\end{array}$ & $50 \times 099$ & 100 w0 249 & 250 or more & Total \\
\hline 1984 & 2 & 2 & $\mathbf{0}$ & 3 & 6 & 13 \\
\hline 1985 & 3 & 1 & 2 & 1 & 2 & 9 \\
\hline 1986 & 0 & 2 & 0 & 2 & 4 & 8 \\
\hline 1987 & 0 & 0 & 3 & 7 & 1 & 13 \\
\hline 1988 & 2 & 2 & 6 & 12 & 2 & 24 \\
\hline 1989 & 0 & 1 & 4 & 4 & $\mathbf{0}$ & 9 \\
\hline 1990 & 4 & 4 & 1 & 0 & 1 & 10 \\
\hline 1991 & 3 & 2 & 3 & 1 & 1 & 10 \\
\hline 1992 & 2 & 1 & 1 & 0 & 0 & 4 \\
\hline Tocal & 16 & 15 & 22 & 30 & 17 & 100 \\
\hline
\end{tabular}

We also gathered documents from informants that record the history of the firm, its organization, and its personnel practices whenever possible (e.g. organization charts, initial business plans, personnel manuals, company forms and documents). In addition, we gathered publicly-available information about each of the firms in the study using a number of on-line database services, including Lexis/Nexis, Dialog Business Connection and ABI Inform, as well as annual reports and 10Ks for each of the public firms. For publicly-traded firms, we obtained a prospectus from the initial public stock offering.

Potential limitations of the SPEC design. As a source of baseline data on the early organizing activities of new enterprises, we believe the SPEC project provides a unique source of data, containing richer quantitative and qualicative information on a larger, more comprehensive and representative sample of organizations than any we have encountered in the literatures on organization-building and entrepreneurship. At the same time, we are well aware of several potential limitations of the SPEC study design. First, we have gathered information about early organization-building activities by asking key individuals involved in those activities for their retrospective recollections, and such recollections are always subject to potential biases. Second, we have asked founders and senior managers to characterize their organizations and human resource practices, but there is no guarantee that their accounts correspond to the reality experienced by employees. Third, although we intentionally limited our sample to organizations that are still quite young (a median age of under six years, with $24 \%$ being four years old or younger), there is nonetheless the possibility of some sort of survivor bias characterizing our sample because we are only informed about the early 
histories, employment models, and organization-building activities of companies that have endured to make it into our sample. These are important concerns that deserve careful considerations accordingly, after reporting our results, we briefly assess whether and how such limications might cloud our analysis and conclusions.

\section{Founders' Models of Employment Systems}

In this paper, we examine the actual employment practices adopted by organizations in their formative years. We also examine how those who created organizations conceived of the employment relationship. It is arguably those conceptions, as much as the specific human resource practices adopted by companies in their infancy, that should influence the subsequent evolution of organizational arrangements and employment practices within their companies. After all, when organizations are still very young and small, they might vary less in the particular HR practices they have put in place than in the preanises that guide how they manage the work-force, which become institutionalized in organizational structures and practices at a later point in time.

Each founder in the SPEC sample was asked whether or not he or she had an organizational model or blueprint in mind when [you] founded the company'. ( $\Lambda$ companion question regarding the present was asked of the current CEO in each firm.) Roughly two-thirds of the founders were able to articulate some kind of HR blueprint, with almost half expressing a very clear organizational model, sometimes citing a specific organization as an illustration of what they wanted their firm to look like (or not to look like). Burton (1995) describes the wide variety of anchetypes on which these founders drew in describing their organizational blueprints, ranging from the academy, to Japanese organizations, to scholarly models of management (e.g. MacGregor's [1960] Theory $X$ and Theory $Y$, to a widely-shared image of 'the typical Silicon Valley start-up'. Others steadfastly disavowed the notion of having a clear organizational model ax ante. As one founder put it: 'Models are a source of failure for start-ups. You have to become a successful company first, then create your own model. Even the celebrated [Hewlett Packard] principles were written twenty years after the company was started.'

Upon analyzing the detailed interview transcripts oboained from each founder, we identified three recurring dimensions along which their images varied reganding how work and employment should be organized: the primary basis of organizational attachment; the primary means for controlling and coordinating work; and the primary criterion to be emphasized in 
selecting employees. Along each of these dimensions, in turn, we found that founders' blueprints tended to cluster into one of three distinct categories. We briefly summarize each of the three dimensions and its constituent subcaregories: ${ }^{2}$

\section{Attachment}

The first dimension along which founders' models vary concerns the primary basis of attachment (and retention) of employees. Three different bases of attachment were articulated by founders in recalling their organizational blueprints, which we label love, work and money.

Some founders indicated that they envisioned that creating a strong family-like feeling and an intense emotional bond with employees would inspire superior effort and increase the chances of retaining highly-sought employees over long periods of time, thereby avoiding the frequent mobility of key technical personnel that plagues Silicon Valley start-ups. One founder stated:

I think people should be treated as human beings, as real people. And really care for them. We are still pretty much like family. We try to keep as much of that as possible even as the company is bigger. Thar's one thing 1 learned from HP [Hewlett-Packard]. Bill Hewlett still Aipped hamburgers for us at the company picnic.

This quote nicely captures the familial associations underpinning this vision-the company picnic as a surrogate for the family barbecue, and the CEO (Bill Hewlett, in the anecdote) as 'Dad'. Thus, what binds the employee to the firm in this model is, simply put, love an intense emotional sense of personal belonging and identification with others in the company, comparable to a family.

A large number of firms in the sample pursue cutting-edge technology, and for their employees a primary motivator is the desire to work at the technological frontier. Recognizing this, many of the founders responses reveal that they presumed that providing opportunities for interesting and challenging work would be the basis for attracting, motivating, and (perhaps) retaining employees. Here, the employees were not expected to be loyal to the firm, or the boss, or even co-workers per se, but instead to the project. As one founder put it:

\footnotetext{
2 Noce that we did nox senucture the interviews explicitly around these three dimentions of their aubcarczories, as these emerged after we had gathered, coded and anlyed the interview tmmacripes. In ocher words, foundes and CEOs were nox asked to clesify theit models along these dimensions or into the specific subcaregories bux instend to provide an open-ended description of their organimational bluepriat and its mainale, which we then coded after the fact.
} 
We wanted to assemble ceams of people who are curned on by difficult problems. The emphasis was to build an environment of individuals who are performance driven, achievement oriented, customer focused, feel relatively at ease to join and disband from specific teams, skilled at interdisciplinary problem solving irrespective of culture or discipline.

Finally, other founders told us that they regarded the employment relationship as a simple exchange of labor for money. One founder put this bluntly:

[My] model is besically 'you work, you get paid.' With an assembly type business there is not a lot of engineering or white-collar workers requiring complex HR benefits or policies. We're not interested in the sof,, warm, fuzry stuff. Of course, we also don't want to be running a sweat shop.

\section{Basis of Control}

A second, related distinction in founders' models or blueprints concerns the principal means of controlling and coordinating work. The most common blueprint involves extensive reliance on peer or cultural control. One founder put this as follows: In my mind and probably in [the co-founder's] mind was that we would be a very open, horizontal company with an emphasis on teamwork and all decisions made by consensus. Employees wear whatever they want, work whenever they want.' It is taken for granted that employees would work long hours, and peer pressure will presumably ensure that this is done and that the hours are spent working on useful endeavors. Not surprisingly, founders who espoused this view also were likely to speak about the importance of socializing employees to ensure that they understood the directions in which their efforts should be aimed.

Other founders recalled that their intention was to rely on professional control, even if they did not explicitly use this terminology. It is clear from their responses that these founders took it for granted that workers were committed to excellence in their work and were able to perform at high levels because they had been professionally socialized to do so. (Not surprisingly, this model tends to be accompanied by an emphasis on recruitment of highpotential individuals from elite institutions.) In this model, the emphasis is on autonomy and independence, rather than on enculturation. One founder told us:

Scientists like autonomy and independence. I value it myself and it's important to make sure that they hive that. They feel the environment is exciting and that the leadership is there to provide the kind of place where their career is constantly renewing and growing. This essentially is most of my work $\rightarrow$ to see that they reach their maximum potential to grow. 
Another founder explained:

I give people a lot of autonomy. You perform for me, I don't care if you ever show up for work . . . So I pue a loc more out there and gave more responsibility and accouncability to the people and didn't monitor on a day to day basis. I truly believe that's the right style in business today.

Finally, a third group of founders espoused a more traditional view of control as being embedded in formal procedurns and systems. The following excerpts from two founder interviews illustrate this perspective well:

We're not hierarchical as much as we are procedures, methodologies, and systems. I really try to see that everybody in the company maintains procedures rather than just hand wave and do things any way. We don't wint to be so hierarchical as to be startling, nor do we want to be so flat as to have everybody poking into everybody else's business.

We run very much on a TQM philosophy. We make sure that things are documented, have job descriptions for people, project descriptions, and pretty rigorous project management techniques.

\section{Selection}

The third source of variation in founders' organizational blueprints, closely related to the preceding two, concerns the primary basis for selecting employees to join the firm. Some founders seemed to think of the firm in terms of bundles of tasks that needed to be carried out, seeking employees to carry out those tasks effectively. Time and money tend to be the paramount concerns here, so the focus was on selecting employees who could be brought on board and be up to speed as soon as possible and who would not decimate the founder's wallet or purse. As one founder put it, "it's not who you know or what you do politically, but what you can achieve technically'. In these cases, the founders envisioned selecting employees who possessed the skills and experience noeded to accomplish some immediate task(s).

In other cases, founders seemed to be focused less on immediate and welldefined tasks than on a series of projects (often not yet even envisioned) through which employees would move over time. Accordingly, their focus in selection was on long-remm posential, rather than on specific skills or relevant vocational experience. One founder articulated this point of view: 'Given the choice between a smart person and an experienced one I'll always rake the smart person. You can't give someone smarts, but you can give them experience.' These founders often also spoke of the importance of reputation, network ties, and other incangible assets in evaluating potential employees.

Finally, another group of founders reported that they focused primarily on 
ualues or cultural fit. Like the previous group, these founders were concerned about the long-term, rather than specific short-term personnel needs, but they put heavy emphasis on how a prospective hire would connect with others in the organization: 'At the scart we were seeking people with a longterm focus - no Valley job hoppers. And we were as concerned with how everyone would fit together as we were with technical ability.'

\section{Relationships Among the Three Dimensions}

Not surprisingly, these three dimensions underlying founders' conceptions of the employment system are not independent. In fact, although we have classified founders into three types on each of the three dimensions, thereby yielding 27 possible combinations, $71 \%$ of the observations for which we were able to code all three dimensions clustered in just three of the cells: a cell combining attachment to work, professional control, and selection based. on potential (16 firms); another combining attachment to work, peer control, and selection based on specific tasks (17 firms); and a third combining attachment through love or emotion, peer control, and selection based on cultural fit (16 firms). The next most populous cells are those involving formal organizational controls and selection for specific skills or tasks, involving either attachment through money ( 6 firms) or through the nature of the work ( 5 firms).

Based on this clustering, we identified four pure-type employment models, reflecting combinations of the three dimensions (Table 2). We use the label 'star' to refer to the model that involves challenging work, autonomy and professional control, and selection of elite personnel based on long-term potential. We use the 'engineering' label for the blueprint combining a focus on challenging work, peer group control, and selection based on specific task abilities. We refer to the blueprint relying on emotional/familial attachments of employees to the organization, selection based on cultural fit, and peer group control as the 'commitment' model. Finally, the 'factory' model is predicated on purely monetary motivations, control and coordination through formal organization and close managerial oversight, and selection of employees to perform pre-specified tasks. That label is intended to capture the similarity between this model and the traditional factory system under early industrial capiralism, which treated employees as factor inputs, preserved discretion of the owner, and relied on a combination of pecuniary rewards, close supervisory oversight, and technical or bureaucratic controls over employees. It also conveniently captures the contemporary pejorative connotation from the employee's perspective, as in the description of a nonmanufacturing workplace as a 'factory'. 
Tabue 2. Pour Pure-Type Employment Models, Based on Three Dimensions'

\begin{tabular}{llll}
\hline & \multicolumn{2}{c}{ Dimensions } & Employment model \\
Atrachment & Selection & Coordination/Control & \\
\hline Work & Pocential & Profeasional & STAR \\
Work & Trak & Peer & ENGINEERING \\
Love & Valuea & Peer & COMROTMGNT \\
Money & Teak & Managerial & PACTORY \\
\hline
\end{tabular}

"Firms that did noc correspond to pure types were asaigned to an ernployment model scoonding to the following rules: (i) Love' as a besis of atrachment indicates a commitment model, regardless of selection criterion or basis of coatrol; (ii) money as a basis of atcachment indicates a factory model; (iii) work as a basis of artachment combined with professional control indicates a seas model, regardless of selection criterion; (iv) work as a basis of artachment without professional concrol indicates an engineeriag model.

The fact that these three conceptual dimensions-the primary basis of attachment, the primary criterion for selecting employees and the primary axis of control and coordination-are interdependent is not a surprise. Rather, the strong association among them is itself suggestive of consistency and complementarities among dimensions of human resource management. Recall that we noted three bases for consistency among HR practices: economic or technical complementarities (doing $\mathbf{X}$ increases the returns from doing $Y$ and vice versa); cognitive or perceptual congruence, which facilitates learning; and congruency with broader social or cultural norms (which also helps to convey expectations and facilitate learning). Founders' HR blueprints for their start-up organizations seem to evidence all three bases of consistency.

For instance, in an organization seeking peer monitoring and in which emotional attachments to the organization itself (rather than to one's specific work assignment) are sought-perhaps to create goal congruence among differentiated subunits-there is a clear technical complementarity with selection mechanisms that screen for cultural fit and values. The very fact that many founders were able to articulate such a clear model or blueprint for how they intended to manage human resources is suggestive of the second rationale we offered for consistency-namely, the virtues of having a simple, coherent and internally consistent image of the employment relationship to communicate expectations and entitlements to employees. Nithough the labels 'star', 'engineering', 'commitment' and 'factory' are our own, we think they capture nicely the role expectations and treatment that typical employees in each type of organization are likely to confront.

Finally, we suggested that there may be benefies for both the firm and its employees when the organization's HR policies resonate with rules, values, and codes of conduct that employees have experienced in other social 
settings. Notice that each of the four pure-type employment models we identified resonates with models or behavional scripts that prevail in other contexts. It can hardly be a coincidence, for instance, that the star employment model, which is espoused particularly by founders of firms developing medical technology, ${ }^{3}$ corresponds so closely to the model that underlies employment relations in academia, where many of the founders and key scientific personnel sought for these start-ups are recruited. The commitment model draws instead, as we have noted, on familial images, encouraging employees to view their associations with the firm in similar terms. The engineering model, arguably the default within Silicon Valley (Sexenian, 1994), dovetails with the socialization that engineers receive in professional school and is well suited to the Valley's highly-mobile labor force, placing more value on 'cool technology' and technical contribution than on organizational loyalty or elite credentials. Finally, the austere, no-nonsense factory model communicates a very powerful and consistent message that employees are certain to have encountered elsewhere before: you work, you get paidnothing more, nothing less.

Given the strong associations among these three dimensions, it is interesting to scrutinize the small number of cases that seem to combine discrepant or discordant foci in the founder's $M R$ model. For instance, one founder claimed to be searching for employees based on their long-term potential, despite an emphasis on formal organizational control and financial remuneration as the basis for attachment. He stated, 'Our main goal is to stay lean and flat. I also recognize that you have to be flexible with your people'. When asked about the organization of work, this founder replied they 'don't have the resources to spend a lot of time getting everyone warm and fuzzy ... we avoid consensus management and everyone knows who calls the shots'. Another founder emphasized values as the basis for selection and emotional or familial attachment to the firm as the primary motivator, but at the same time espoused a belief in the importance of formal controls. This firm is a family business, and it recruits employees primarily from the surrounding neighborhood and church community. The founders expected employees to be extremely fexible in their work orientation and willing to do all phases of the work, including sales, customer support and training. However, they also micro-managed the organization, insisting, for ecample, that a salesman who lived in Palo Alto and covered the Palo Alto geographic region drive some thirty miles each moming by 8 am to check in the office. An interesting question for subsequent research based on these data, after we have completed the intended follow-up visits to these companies, is

3 Of the 15 firm in the medical secwer (induding biocechnologs), $80 \%$ were founded with a seas model, compred to $16.7 \%$ mong the remaining fime $\left(r^{2}=24.9\right.$, of $\left.-1, p<0.001\right)$. 
whether organizational evolution and performance differ as a function of the internal consistency exhibited in firms' initial HR blueprines and practices.

\section{Organizational Consequences of Founders' HR Blucprints}

If consistency among HR practices and/or in treatment across different segments of the work-force is important, then we should detect several forms of (indirect) evidence by examining how HR systems evolve in organizations characterized by different underlying blueprints or models. First, we would expect to see systematic differences among firms, as a function of their initial HR models, in the prevalence of certain HR practices and the speed with which they were adopted. For example, we would expect that organizations embracing a commitment model are most likely (and fastest) to adopt policies and practices designed to bind employees to the organization (socialization, communication, etc.) and to undertake investments in the work-force (such as training and promotion from within) that are predicated on longterm attachments.

Second, it seems reasonable to expect that the HR models would differ in the extent to which they encourage versus discourage consistent treatment among diverse segments of the work-force. In this regard, the commitment model lies at one end of the spectrum, encouraging all employees to identify themselves as members of a single corporate family. The scar and factory models seem most receptive to distinctions among individuals (based on ability and/or market forces). Accordingly, we would expect firms founded along the lines of the commitment model are less likely (and slower) than companies embracing the star or factory model to adopt compensation arrangements, job descriptions and other HR practices that differentiate among workers.

We collected daca on the timing of the adoption of a broad set of practices and procedures related to human resource management. Of course, one possibility is that a firm has not yet adopted a given practice, in which case the record on that practice is right-censored. We use two approaches in analyzing variations in the speed of adoption as a function of the founder's employment model. One approach emphasizes early adoption, we chose to focus on the company's first two years of operation. In this analysis, we distinguish firms that adopted a given HR practice or document within the first two years from all others (combining both later adopters and non-adopters). The advancage of focusing on the early period is that founders' HR models are likely to be stable over this short period; the disadvantage is that this form of analysis does not take full advantage of the data, ignoring information on 
Table 3. Effects of Founder's HR Model on Log-Odds of Implementing Various HR Policies and Documents within the First Two Years of Business: Multinomial Logit Regressions $(n=69)$.

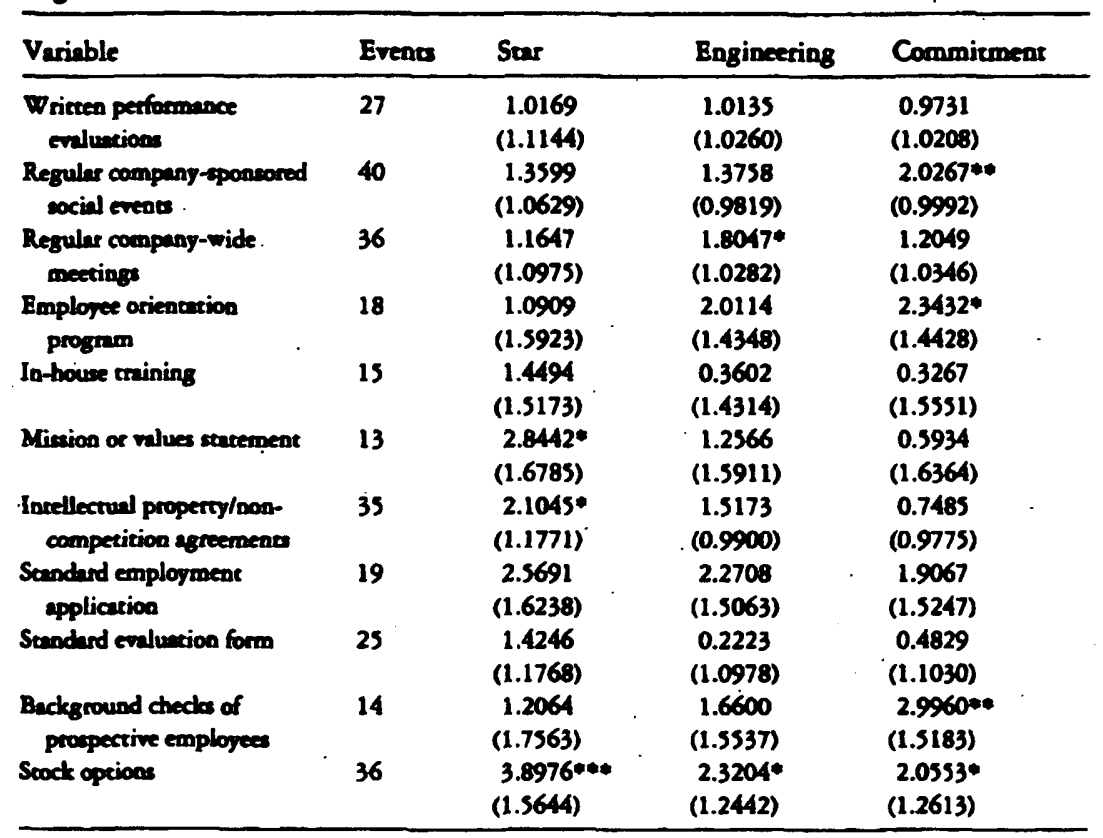

Note: effeces of sixe and indusery are not reported; figures in parentheses are standard errors. $* 0.10 * p<0.05 * * *_{p}<0.01$.

timing within the first two years as well as information on the histories over the subsequent years ( 4.5 years, on average). We therefore supplement these analyses with a second approach, which analyzes the complete company histories and distinguishes between non-adopters and adopters. The advantages and disadvantages of this strategy are obviously the mirror image of those of the alternative.

Adoption of HR Policies and Documents within the First Two Years of Business

Table 3 reports results based on the first strategy: distinguishing firms that adopted particular HR policies and practices with their first two years of operation from the others. This Table reports estimates of the effects from a series of multinominal logit regressions. The estimated effects reported show differences in the log-odds of having adopted various human resource policies (or produced various HR documents) by the end of the firm's second 
year in existence. ${ }^{4}$ These analyses control for industry (computer hardware and software, semiconductors, telecommunications, manufacturing and research were included as dummy variables, with medical-related as the omitted category) and for the number of employees each firm had by the end of its second year of operations. The columns of coefficients reported in Table 3 express the net difference in the log-odds of having adopted or implemented a given HR practice within the first two years of business between those firms founded with a particular HR model (star, engineering, commitment) and firms founded with the factory model (the omitted category).

Not surprisingly, it is clear from Table 3 that firms whose founders conceived of employment in factory terms were less likely to adopt virtually every type of HR policy and document, relative to otherwise-comparable firms that began with a star, engineering, or commitment model.' According to Table 3, firms whose founders espoused a star model of employment were considerably more likely to institute intellectual property or noncompete agreements and stock options within the first two years than otherwise-similar firms with a different HR blueprint, and the contrast between the star and factory categories is statistically significant in both instances. (Firms in the engineering and commitment categories are considerably less likely to grant stock options than those in the star category, but still significantly more likely to do so than firms in the factory category.) Given the. dependence of star films on key technical personnel, these findings are quite sensible, suggesting that the organization acted quickly to seek to bind their key technical employees over the long-term and reduce the likelihood of their leaving.

Star firms were also significantly more likely than those with a factory model by having adopred a mission or values statement by the end of the second year. This result might suggest an effort to achieve similar ends by promoting a distinctive corporate identity very early with which key employees could identify. Alternatively, perhaps their need to recruit key

\footnotetext{
4 The precise time at which an organization is boen' is berlly semightforward. For the purpose of this analysis, a birch dace was defined the corresponded to the earliest evidence of a formal organimetion. The main defining criceria were: (i) legal incorporacion; (ii) beving at least one person engaged in the encerprise full-time; or (iii) selling a product or service. This definition eliminates the possibility of humen resource systems or penctices being implemenced before there was an existing frm. Unforrunaty, it also cornplicates the inverperacion of effects. Some fims are defined as implementing $\mathrm{HR}$ ssuems when there is a single founder working on a business plan that happens to isclude a mention of bow furure conplores will be creaced, wheress otber frms are defined as implementing syetems and practios well afver emplojecs have been hired and produces have been sald.

Noce that a number of coefficients in Table 3 are quive bage, but wo are their sundard errots, due to the selatively small sample sixe and the small aumber of firms heving adopeed certain HR pactices of documents. (Table $3 \mathrm{colly}$ repores resuls for those HR policies and documents chat had been adopeed by cee ar mone firms within the frest ren years.)
} 
technical personnel from outside the labor pool of experienced Silicon Valley engineers encourages such firms to espouse their mission and values clearly to artract the best scientific and technical employees. According to Table 3, firms that began with the star model were also the most likely to have promulgated job descriptions, standard employment applications, and standard performance evaluation forms by the end of their second year. Although not staristically significant, these results are broadly consistent with the interest such firms have in attracting top-flight scientific and technical personnel and being able to evaluate who are the stars. Moreover, they might provide management with a sense of exercising some organizational control over autonomous professionals.

Table 3 also reveals that firms having embarked with a commitment model were the most likely to have implemented background checks of prospective employees, to conduct formal employee orientation programs, and to sponsor regular social events for employees. They are significantly more likely to do so than otherwise comparable organizations whose founders espoused a factory blueprint for HR. These findings suggest that, having created an organization with the intention of creating long-term relations with employees, management goes to greater lengths to screen prospective hires, is more engaged in formally orienting them to the organization, and does more to provide for employees' social welfare.

That we are able to detect differences in the existence of particular employment practices so early in the lives of these organizations, and after controlling for industry and employment size within the first two years, indicates that founders' HR blueprints were not merely thetoric but instead exerted a significant effect on the evolution of employment relations within these companies. Moreover, our results suggest that, even within the first two years, the HR systems of these organizations are exhibiting complementarities among particular HR practices.

\section{Time to Adoption of HR Policies and Documents}

Table 4 looks at the same issue in a slightly different way, which provides us with more statistical power to detect differences among the four employment models. Most organizations in our sample (and, we suspect, in general) are not doing a great deal to formalize employment relations within their first two years. Consequently, for a number of $H R$ policies and documents of interest, there is not much variation in adoption within the first two years to be analyzed. In Table 4, we take advantage of each firm's entire history and information obcained from surveys and interviews on the timing of arious HR practices to examine whether there are significant differences 
in the speed of implementing various HR practices across the four HR models.

For this purpose, we use event history techniques (Tuma and Hannan, 1984) to estimate the effects of the founder's HR model (and other covariates) on the rate of adopting the various $H R$ practices and documents listed in Table $4 .^{6}$ We specify the underlying process in terms of organizational age $(t)$, which we regard as continuous. That is, we regard each firm as becoming at risk of adopting each of the HR practices at birth, and we analyze the (right-censored) distribution of age at the time of adopting. ' Let $Y_{k}(t)$ be a random variable that indicates whether a firm has adopted practice $k$ at age $t, Y_{k}(t)=0$ if the firm has not yet adopted and $Y_{k}(t)=1$ if it has. We specify the effects of the founder's employment model (relative to the 'factory model', which is the omitted category) and of other covariates on the (instantaneous) transition rate or hazard as:

$$
r_{k}(t)=\frac{\lim \operatorname{Pr}\left[Y_{b}(t+\Delta t)=1 \mid Y_{t}(t)=0\right]}{\Delta t+0}
$$

Table 4 reports estimates of Gompertz models with the following specification:

$$
\begin{gathered}
r_{k}(t)=b_{k} \exp \left(c_{k} t\right), t>0 ; \\
b_{k}=\exp \left(B_{k} \beta_{k}\right) \\
c_{k}=\exp \left(\gamma_{k}\right) .
\end{gathered}
$$

Here, $B_{k}$ is a matrix of observations on a set of covariates that are updated annually using the standard method of 'spell splitting' (Tuma and Hannan, 1984). The covariates included are industry dummies and age-varying organizational size (employee headcount at the start of each year of observation). ${ }^{8}$

Before examining how founders' HR blueprints influence the adoption of specific HR policies and documents, it is interesting to consider the effects of ageing and employment growth. Considering the full set of 25 outcomes in Table 4, it is clear that growth in employment dominates organizational ageing in determining the rates at which start-up companies adopt HR policies and documents. Table 4 shows that size has significant effects on the rates of adoption for 18 of the 25 practices; each of the significant effects is positive. The effects of growth are largest and most often significant for HR

\footnotetext{
- Table 4 repores resulas for those HR policies and documenes that had been edopeed by ax lasse menty frrns during their entire hiswories.

7 One frm reported adopting, and then later abendoning wituen job descriptions. The models prerenced in this paper do not eccount for such reverse cmasitions.

- The models were extimered in TDA 5.7 (Rotmer, 1994).
} 
TABuE 4. Effects of Founder's HR Model, Size, and Age on the Rates of Adopting Various HR Policies and Documents: Gompertz Models ( $n=69)^{4}$

\begin{tabular}{|c|c|c|c|c|c|c|}
\hline Variable & Evenes & Sant & Engineering & Commitment & Size & Age \\
\hline $\begin{array}{l}\text { Writuen petiormance } \\
\text { evluations }\end{array}$ & 62 & $\begin{array}{c}0.833 \\
(0.519)\end{array}$ & $\begin{array}{l}1.191 * * \\
(0.484)\end{array}$ & $\begin{array}{l}1.191 * * * * \\
(0.467)\end{array}$ & $\begin{array}{l}0.005 * \\
(0.002)\end{array}$ & $\begin{array}{c}0.007 \\
(0.005)\end{array}$ \\
\hline Organimetion char & 57 & $\begin{array}{c}0.528 \\
(0.476)\end{array}$ & $\begin{array}{c}0.053 \\
(0.439)\end{array}$ & $\begin{array}{c}0.158 \\
(0.472)\end{array}$ & $\begin{array}{r}-0.0003 \\
(0.002)\end{array}$ & $\begin{array}{l}0.019 * \\
(0.000)\end{array}$ \\
\hline $\begin{array}{l}\text { Reguler social } \\
\text { events }\end{array}$ & 61 & $\begin{array}{l}1.231 * \\
(0.520)\end{array}$ & $\begin{array}{c}0.630 \\
(0.471)\end{array}$ & $\begin{array}{l}1.153^{* * * *} \\
(0.445)\end{array}$ & $\begin{array}{l}0.005 * * \\
(0.002)\end{array}$ & $\begin{array}{r}-0.013 \\
(0.063)\end{array}$ \\
\hline $\begin{array}{l}\text { Regular company- } \\
\text { vide meetings }\end{array}$ & 62 & $\begin{array}{c}0.784 \\
(0.469)\end{array}$ & $\begin{array}{c}0.524 \\
(0.433)\end{array}$ & $\begin{array}{c}0.257 \\
(0.442)\end{array}$ & $\begin{array}{l}0.005^{*} \\
(0.002)\end{array}$ & $\begin{array}{c}-0.014 \\
(0.006)\end{array}$ \\
\hline $\begin{array}{l}\text { Employee } \\
\text { orientation prognm }\end{array}$ & 49 & $\begin{array}{l}1.376^{\circ} \\
(0.593)\end{array}$ & $\begin{array}{c}0.843^{\circ} \\
(0.497)\end{array}$ & $\begin{array}{l}1.201 * * \\
(0.493)\end{array}$ & $\begin{array}{l}0.010^{\infty} \\
(0.002)\end{array}$ & $\begin{array}{r}-0.002 \\
(0.005)\end{array}$ \\
\hline $\begin{array}{l}\text { Company-wide } \\
\text { electronic mail }\end{array}$ & 49 & $\begin{array}{l}1.692 * * * \\
(0.567)\end{array}$ & $\begin{array}{c}0.549 \\
(0.515)\end{array}$ & $\begin{array}{c}0.805 \\
(0.498)\end{array}$ & $\begin{array}{l}0.005 * * \\
(0.002)\end{array}$ & $\begin{array}{r}-0.003 \\
(0.006)\end{array}$ \\
\hline In-house trining & 43 & $\begin{array}{c}0.946 \\
(0.645)\end{array}$ & $\begin{array}{c}0.885 \\
(0.530)\end{array}$ & $\begin{array}{l}0.963^{\circ} \\
(0.513)\end{array}$ & $\begin{array}{l}0.009 * * * \\
(0.002)\end{array}$ & $\begin{array}{r}0.0001 \\
(0.006)\end{array}$ \\
\hline $\begin{array}{l}\text { Miscion or vilues } \\
\text { stacement }\end{array}$ & 44 & $\begin{array}{c}1.080 \\
(0.590)\end{array}$ & $\begin{array}{c}0.257 \\
(0.540)\end{array}$ & $\begin{array}{c}0.327 \\
(0.533)\end{array}$ & $\begin{array}{l}0.004 * 4 * \\
(0.001)\end{array}$ & $\begin{array}{c}0.004 \\
(0.005)\end{array}$ \\
\hline $\begin{array}{l}\text { Emplogee } \\
\text { suggetion syoem }\end{array}$ & 22 & $\begin{array}{c}0.787 \\
(0.929)\end{array}$ & $\begin{array}{r}-0.722 \\
(0.986)\end{array}$ & $\begin{array}{c}1.182 \\
(0.755)\end{array}$ & $\begin{array}{c}0.001 \\
(0.001)\end{array}$ & $\begin{array}{c}0.014^{*} \\
(0.007)\end{array}$ \\
\hline Newaletter & 26 & $\begin{array}{c}1.246 \\
(0.957)\end{array}$ & $\begin{array}{l}1.757 * * \\
(0.753)\end{array}$ & $\begin{array}{l}2.214 * * * \\
(0.797)\end{array}$ & $\begin{array}{l}0.008^{*} \\
(0.002)\end{array}$ & $\begin{array}{l}0.017 * * \\
(0.006)\end{array}$ \\
\hline $\begin{array}{l}\text { Intellectual property/ } \\
\text { non-compericion } \\
\text { agreernenos }\end{array}$ & 57 & $\begin{array}{l}1.053 \\
(0.489)\end{array}$ & $\begin{array}{c}0.494 \\
(0.442)\end{array}$ & $\begin{array}{r}-0.069 \\
(0.460)\end{array}$ & $\begin{array}{l}0.005^{*} \\
(0.002)\end{array}$ & $\begin{array}{c}-0.012 \\
(0.006)\end{array}$ \\
\hline $\begin{array}{l}\text { Seandardized } \\
\text { employment } \\
\text { applicarion }\end{array}$ & 52 & $\begin{array}{l}1.396 * \\
(0.626)\end{array}$ & $\begin{array}{l}1.048 * 4 \\
(0.529)\end{array}$ & $\begin{array}{l}1.065 * 4 \\
(0.541)\end{array}$ & $\begin{array}{c}0.004 * \\
(0.002)\end{array}$ & $\begin{array}{c}0.004 \\
(0.006)\end{array}$ \\
\hline $\begin{array}{l}\text { Sendard performance } \\
\text { evaluation focm }\end{array}$ & 63 & $\begin{array}{l}1.089 \\
(0.510)\end{array}$ & $\begin{array}{c}0.530 \\
(0.487)\end{array}$ & $\begin{array}{c}0.636 \\
(0.467)\end{array}$ & $\begin{array}{l}0.005 \\
(0.002)\end{array}$ & $\begin{array}{c}0.008 \\
(0.005)\end{array}$ \\
\hline $\begin{array}{l}\text { Background hedos } \\
\text { of proupective } \\
\text { employees }\end{array}$ & 32 & $\begin{array}{c}0.781 \\
(0.760)\end{array}$ & $\begin{array}{c}0.317 \\
(0.689)\end{array}$ & $\begin{array}{l}1.774 * * * \\
(0.577)\end{array}$ & $\begin{array}{l}0.007 * * * \\
(0.002)\end{array}$ & $\begin{array}{r}-0.009 \\
(0.008)\end{array}$ \\
\hline $\begin{array}{l}\text { Personnel manuel } \\
\text { of handbook }\end{array}$ & 56 & $\begin{array}{c}0.849 \\
(0.527)\end{array}$ & $\begin{array}{c}0.436 \\
(0.443)\end{array}$ & $\begin{array}{c}0.248 \\
(0.448)\end{array}$ & $\begin{array}{l}0.003 * * \\
(0.001)\end{array}$ & $\begin{array}{l}0.014 \\
(0.004)\end{array}$ \\
\hline $\begin{array}{l}\text { Written job } \\
\text { descriptions }\end{array}$ & 37 & $\begin{array}{c}0.827 \\
(0.555)\end{array}$ & $\begin{array}{c}0.021 \\
(0.634)\end{array}$ & $\begin{array}{c}0.335 \\
(0.550)\end{array}$ & $\begin{array}{c}0.0004 \\
(0.001)\end{array}$ & $\begin{array}{l}0.026 * 4 \\
(0.006)\end{array}$ \\
\hline $\begin{array}{l}\text { Writcen affirmative- } \\
\text { ection plans }\end{array}$ & 33 & $\begin{array}{c}1.327^{\circ} \\
(0.696)\end{array}$ & $\begin{array}{c}0.083 \\
(0.578)\end{array}$ & $\begin{array}{c}0.611 \\
(0.581)\end{array}$ & $\begin{array}{l}0.009 * * * \\
(0.002)\end{array}$ & $\begin{array}{l}0.017 * * 4 \\
(0.006)\end{array}$ \\
\hline $\begin{array}{l}\text { Human resources } \\
\text { information syutem }\end{array}$ & 35 & $\begin{array}{r}1.279 \\
(0.730)\end{array}$ & $\begin{array}{c}0.429 \\
(0.627)\end{array}$ & $\begin{array}{l}1.452 * 4 \\
(0.612)\end{array}$ & $\begin{array}{l}0.012^{* * *} \\
(0.002)\end{array}$ & $\begin{array}{c}0.001 \\
(0.005)\end{array}$ \\
\hline Stock options & 56 & $\begin{array}{l}1.113^{* *} \\
(0.519)\end{array}$ & $\begin{array}{c}0.740^{\circ} \\
(0.433)\end{array}$ & $\begin{array}{c}0.490 \\
(0.474)\end{array}$ & $\begin{array}{r}-0.001 \\
(0.020)\end{array}$ & $\begin{array}{r}-0.006 \\
(0.006)\end{array}$ \\
\hline $\begin{array}{l}\text { Knowledge or skill- } \\
\text { based pas }\end{array}$ & 30 & $\begin{array}{c}0.116 \\
(0.922)\end{array}$ & $\begin{array}{c}1.296 \\
(0.753)\end{array}$ & $\begin{array}{l}2.657 * 4 * \\
(0.695)\end{array}$ & $\begin{array}{c}-0.003 \\
(0.003)\end{array}$ & $\begin{array}{c}-0.002 \\
(0.005)\end{array}$ \\
\hline $\begin{array}{l}\text { Individual incentives } \\
\text { of bonuses }\end{array}$ & so & $\begin{array}{c}0.837 \\
(0.573)\end{array}$ & $\begin{array}{c}0.490 \\
(0.482)\end{array}$ & $\begin{array}{c}0.659 \\
(0.454)\end{array}$ & $\begin{array}{c}0.003 \\
(0.002)\end{array}$ & $\begin{array}{c}-0.002 \\
(0.005)\end{array}$ \\
\hline Signing bonus & 21 & $\begin{array}{c}1.202 \\
(0.910)\end{array}$ & $\begin{array}{c}0.731 \\
(0.839)\end{array}$ & $\begin{array}{c}0.397 \\
(0.857)\end{array}$ & $\begin{array}{c}0.002 \\
(0.003)\end{array}$ & $\begin{array}{c}-0.005 \\
(0.008)\end{array}$ \\
\hline $\begin{array}{c}\text { Profit sharing of } \\
\text { gain sharing }\end{array}$ & 25 & $\begin{array}{c}1.402 \\
(0.845)\end{array}$ & $\begin{array}{c}0.349 \\
(0.795)\end{array}$ & $\begin{array}{l}1.5990 \\
(0.748)\end{array}$ & $\begin{array}{l}0.002 * \\
(0.001)\end{array}$ & $\begin{array}{c}0.003 \\
(0.007)\end{array}$ \\
\hline
\end{tabular}


TABLB 4. (come)

\begin{tabular}{ccccccc}
\hline $\begin{array}{c}\text { Non-monetary awneds } \\
\text { for perforthence }\end{array}$ & -0.399 & $1.149 *$ & 0.129 & 0.001 & 0.004 \\
Group/team incencives 25 & $(0.851)$ & $(0.698)$ & $(0.684)$ & $(0.001)$ & $(0.007)$ \\
of bonuses & 0.712 & -0.242 & 0.103 & $0.005 * *$ & 0.001 \\
\hline & & $(0.700)$ & $(0.748)$ & $(0.610)$ & $(0.002)$ & $(0.007)$ \\
\hline
\end{tabular}

Nore: effects of industry caregories are not reported. Figures in parentheses are standand erron. $p<0.10 * * * 0.05 * * * p<0.01$.

issues other than compensation, particularly those pertaining to formalization and standardization of employment relations and institutionalizing means of socialization and communication (regular social events and meetings, newsletters, e-mail, orientation programs, training). Interestingly, the effect of growth is non-significant for all of the items involving individual rewards (stock options, skill-based pay, individual bonuses, signing bonuses, and non-monetary rewards). However, employment growth does significantly increase. the rate of adopting two forms of reward based on groups or teams: profit or gain sharing and group- or team-based incentives and bonuses. One obvious possible explanation for these results is that increases in the scale (and diversity) of employment entail greater potential for freeriding, as well as more possibility for goal conflict, necessitating groupbased reward systems. Another explanation, not inconsistent with the previous one, is that technology firms develop their work-forces by adding manufacturing and marketing capacity after having completed the initial research and development phase, and the interdependencies among engineering, manufacturing and marketing created by this transition are reflected in new compensation arrangements based on group- or companywide performance.

The effect of time-varying organizational age ( $c_{k}$ in equation 4$)$ is statistically significant for only seven of the 25 HR practices; two of the significant effects are negative and five are positive. The practices for which the rate of adoption increases with age tend to involve formalization in the purest sense of creating documents that specify employment structures and procedures and provide organizational 'memory': organization charts, newsletters, personnel manuals, written job descriptions and written affirmative action plans. Irrespective of size, as organizations age they appear less likely to adopt intellectual property or non-competition agreements for 'star' employees or to implement regular company-wide meetings, which seems consistent with the above-mentioned notion of a transition from dominance by key engineering personnel in the early years to more interdependence among (increasingly specialized) functional areas that include manufacturing and 
marketing. Overall, Table 4 suggests that employment growth dominates aging per se in determining adoption of the sorts of $\mathrm{HR}$ practices and procedures that we examined.

Table 4 reveals significant differences across the four $H R$ models in the rate of implementing various employment policies and documents. In fact, of the 25 outcomes analyzed in Table 4, there are statistically significant differences by founder's HR blueprint for 18 (72\%) of them, even after controlling for company age and time-varying employment size. The results in Table 4 generally corroborate those in Table 3 . Table 4 shows that firms that began with a factory model were slower to adopt almost every type of HR policy or document listed. Bearing in mind that the statistical models in Table 4 control for industry and time-varying employment size, this is fairly strong evidence of path dependence in the evolution of employment systems. Table 4 also provides some additional evidence of differences in the evolution of HR systems as a function of the founder's blueprint. Relative to the factory model, firms whose founders embraced the three other models were somewhat faster to develop standardized employment applications, performance evaluations, newsletters, HR information systems, employee orientation programs, in-house training, social events and/or company-wide meetings, and compensation in the form of skill-based pay, profit sharing or gain sharing or stock options. (A few of these contrasts vis-d-vis the omitted category are not statistically significant.) Given the long-term attachments with employees sought through the commitment model, it is hardly surprising to find that these firms were faster than their factory-model counterparts in the same industry and with the same headcount to develop HR information systems, formalize performance evaluation, develop various policies and documents aimed at internal communication and socializing, provide in-house training, tie compensation to accumulated knowledge and skill, and share corporate profits or efficiency improvements with the workforce through profit sharing or gain sharing.?

Interestingly, a number of the same developmental tendencies are exhibited among firms that embraced an engineering HR model. However, the latter firms seem especially inclined to emphasize stock options and nonmonetary recognition awards (both of which seem to be part of the engineering culture), and, relative to firms espousing the commitment model, they were more likely to eschew HR activities that systematize employment relations and HRM (organizational charts, job descriptions, HR information

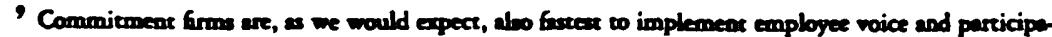

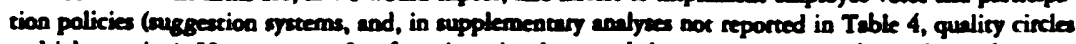
and job roution). However, 000 few firms have implemented these parctices wo enable stable and precire eximates of the soxistical effects.
} 
systems), particularly practices aimed at facilitating equity, consistency and a shared identity throughout the organization's entire work-force (profitsharing and gain-sharing, affirmative action plans, suggestion systems, company-sponsored social events). In other words, consistent with our description of the engineering pure type, there is less evidence of a "corporate' focus in the evolution of HR activities in firms that embarked with the engineering model; after all, engineers value 'cool technology', not cuttingedge management philosophies.

The results pertaining to the star model suggest a pre-eminent focus on adopting HR practices in order to facilitate selecting, differentiating, and rewarding the firm's stars (and justify this to external partners and investors). Consistent with Table 3, Table 4 shows that firms that began with a star model were faster than otherwise comparable enterprises founded with a factory model of employment to develop intellectual property (noncompetition) agreements and stock options. They were also faster to implement standardized forms for evaluating performance, which is sensible given the focus on rewarding and retaining star performers. That focus might also explain several other results for star frms in Table 4. For instance, they implemented affirmative action plans at the highest rate; presumably, the imperative of identifying and recruiting the most talented individuals, whatever their gender or ethnicity, is nowhere stronger than in organizations embracing the star model. This might also explain their higher rate of developing human resource informations systems.

Several results in Table $\mathbf{4}$ regarding the star firms might seem less intuitive, such as their faster adoption of company-wide electronic mail, company-wide meetings, social events, mission statements and profit-sharing. We noted previously that star firms are often crafted on the model of academia, where reliance on e-mail and regular seminars and meetings ensures dissemination of the latest research results to colleagues (and where affirmative action plans are commonplace and viewed as legitimate). Furthermore, recognizing that these firms are generilly in a technology race against competitors, with a fairly long lag until results of research can be commercialized and obtain regulatory approval, the reliance of these firms on such practices as mission statements and profit sharing might serve as complements to the stock grants often made to key employees in these companies, designed to keep their attention focused on the company's long-term strategic objectives and to reward them if those objectives are achieved.

We do nor wish to overemphasize these scatistical results, which are preliminary and certainly not unequivocal. Nonetheless, taken together, we believe the evidence we have presented on founders' conceptions of employ- 
ment systems and how those conceptions shape early developments in their firms is strongly suggestive of the importance of consistency and complementarities within HR systems. Moreover, the findings suggest that the relevant unit for transaction cost economizing in designing employment relationships and governance structures may vary from organization to organization. For example, we found some evidence indicating that in enterprises embracing a star or factory model, employment practices appear to be tailored to particular work roles or even in some cases to specific key individuals. In firms embracing a commitment model, however, HR practices appear to promote stronger emphasis on consistent and equal treatment throughout the work-force; employment practices and governance regimes seem to be tailored not to the exigencies of specific work roles or subunits but instead to the needs and interests of the 'family' as a whole. The engineering model seems to be intermediate between these two extremes.

\section{Time to First Full-time Human Resource Manager}

As we have seen, firms in the SPEC sample differ considerably in the degree and speed with which they have formalized and elaborated human resource management. One event that signals a firm's commitment to elaborate and formalize HRM is appointing a full-time manager of human resources. At one extreme, some SPEC firms hired experienced human resource managers almost at the start; in one firm, it was the fourth employee hired, and in another, it was the eighth employee. The founder/CEO of another firm in the sample (with 380 employees at the time we interviewed him) reported that he has always regarded himself as the firm's HR manager because this function is too important to be delegated. At the other extreme, founders and CEOs of some other firms reported that they regard HRM as a frill at best and, at worst, an impediment to business activity. One founder and his administrative assistant handled all HR-related activities until the firm exceeded 300 employees. They were forced to employ a full-time personnel manager when a major government contract was withheld due to EEOC non-compliance. Given this extreme variation, we naturally wondered whether initial blueprints or models of the employment relation could account for some of the variation in the speed with which companies hired a full-time HR specialist.

We obtained information on the exact dace when the first full-time HR manager was hired or appointed from within. Figure 2 reports the estimated cumulative hazard function for this event as a function of organizational age. The rate of hiring the first full-time HR manager increases fairly regularly 
TABuE S. Effects on Rates of Hiring a Full-Time HR Manager: Weibull Models $(n=67)$

\begin{tabular}{|c|c|c|c|}
\hline & (1) & (2) & (3) \\
\hline \multicolumn{4}{|l|}{ A-vector } \\
\hline \multirow[t]{2}{*}{ Constant } & -7.98 & -7.90 & -7.79 \\
\hline & $(-7.33)$ & $(-7.70)$ & $(-7.42)$ \\
\hline \multirow[t]{2}{*}{ Size } & 0.044 & 0.047 & 0.047 \\
\hline & (3.77) & $-(3.93)$ & (3.87) \\
\hline \multirow[t]{2}{*}{ Public company } & 0.933 & 0.792 & 0.818 \\
\hline & (1.92) & (1.67) & $(1.68)$ \\
\hline \multirow[t]{2}{*}{ Telecom/nerworking } & .807 & 1.03 & 0.994 \\
\hline & (2.18) & (2.77) & (2.58) \\
\hline \multirow[t]{2}{*}{ Medical technology } & 0.643 & 0.136 & 0.112 \\
\hline & (1.47). & $(0.315)$ & $(0.253)$ \\
\hline \multicolumn{4}{|l|}{ Founder HR model: } \\
\hline \multirow[t]{2}{*}{ commitmenx } & 2.08 & 0.877 & 0.711 \\
\hline & $(2.36)$ & $(1.27)$ & $(0.987)$ \\
\hline \multirow[t]{2}{*}{ Soar } & 2.13 & 1.13 & 0.967 \\
\hline & (2.50) & (1.72) & $(1.41)$ \\
\hline \multirow[t]{2}{*}{ Engineerting } & 2.44 & 0.854 & 0.760 \\
\hline & (2.73) & (1.21) & (1.05). \\
\hline \multicolumn{4}{|l|}{ Founder's structegy: } \\
\hline \multirow[t]{2}{*}{ Technology race } & & 1.31 & 1.20 \\
\hline & & (2.38) & $(2.10)$ \\
\hline \multirow[t]{2}{*}{ Technology enhancement } & & 1.13 & 0.990 \\
\hline & & (1.95) & (1.63) \\
\hline \multirow[t]{2}{*}{ Hybrid } & & 1.54 & 1.45 \\
\hline & & (2.41) & (2.19) \\
\hline \multirow[t]{2}{*}{$\cos t$} & & -3.03 & -3.29 \\
\hline & & $(-1.08)$ & $(-1.93)$ \\
\hline \multirow[t]{2}{*}{ Non-founder CEO } & & & 0.488 \\
\hline & & & $(1.37)$ \\
\hline \multicolumn{4}{|l|}{ B-vector } \\
\hline Constant & 0.163 & 0.190 & 0.144 \\
\hline \multirow{2}{*}{ Size } & -0.007 & $\begin{array}{r}(1.3) \\
-0.006\end{array}$ & -0.006 \\
\hline & $(-5.51)$ & $(-5.29)$ & $(-5.25)$ \\
\hline Log-likelihood & -314.2 & -305.6 & -304.6 \\
\hline Number of spells & 7193 & 7193 & 7193 \\
\hline Number of everis & 67 & 67 & 67 \\
\hline
\end{tabular}

Figures in parentheses are t-statistio.

at least eight-times higher, according to column 1 in Table $5 .{ }^{10}$ Column 3 in Table $S$ adds an effect for having a non-founder CEO in order to determine whether departure of the founder precipitates hiring of a full-time HR manager (perhaps to implement a new model of employment relations

10 As we document in our companion paper (Hamnen o d., 1996), there is a strong sesociation berween the founder's HR blueprint and the business strusegy that he or she envisioned. Analyses reported in column 2 of Table 5 menealed that frms whose founders incended 10 compete based on technologs were significandy fereer in hiring a full time HR Managet than those incending to compete bed on superior marketing and/or service, which in rum were fuster than those intending to compete besed on cost minimiration. As column 2 revenls the effects of the founder's HR moded are weakened subsenntially (and rendered scaristically insignifiont) after ineroducing concrob for founder's incended business strategy. 
espoused by the new chief executive). However, according to Table 5, this addition does not improve the model fit significantly.

These results suggest that even taking into account a firm's industry, early employment growth, and top executive succession, the founder's HR blueprint has a strong independent effect on the speed with which a fulltime HR manager is employed. Companies whose founders espoused a more 'HR-intensive' blueprint (the star and commitment models) hire HR specialists much sooner than otherwise-comparable companies that embark with a different employment model, suggesting that their blueprints were not mere thetoric but borne out in practice.

\section{Methodological Concerns}

We noted above several potential limitations of the SPEC design that should be borne in mind in interpreting these results, especially: (i) possible retrospective recall bias by our informants; (ii) a potential disjuncture between how top management informants characterized HR practices and the reality experienced by employees in their firms; and (iii) survivor bias and non-random response. We briefly address each of these.

Recall bias. There is an obvious danger in asking individuals who have designed and/or managed companies to reconstruct past events. For instance, informants may unconsciously use current practice to infer a model or set of principles that guided the organization in its early years, even when none existed. Similarly, some HR models and practices may be more socially desirable than others, coloring how informants portrayed their frms and responded to our interviews.

Although we obviously cannot rule out entirely the possibility that such biases plague our results, we think their likely impact is minimal for several reasons. First, in most of the firms we studied (82\%), information on the outcomes analyzed in this paper-che presence and timing of $H R$ practices and documents and a full-time HR manager-came from a different respondent than the person who provided information on the firm's initial strategy, HR model, and early history. Second, the resules reported in this paper and our companion article (Hannan ot al., 1996) do not differ appreciably if we subdivide firms into those in which a single respondent-versus multiple informants-provided all of the information on which our analyses were based. Third, if recall biases are at work, we would expect to see a difference in patterns of association as a function of firm age, with the oldest firms in the sample exhibiting the strongest tendency for respondents to selectively reconstruct the past. However, supplementary analyses failed to unearth 
such a pattern. Fourth, we reiterate that respondents were not specifically asked (or told) about the three dimensions of human resource management on which our taxonomy of models was based, or the specific categories on each dimension, or the four HR models we derived. " Rather, we used openended responses from the interviews to identify these key dimensions and categories and to develop the ideal-type HR models.

Of course, there is always a danger in using information in a sample to develop a typology that is then used to 'explain variance' among the same observations. For that reason, we have since gathered comparable data for another 72 start-up companies, which will enable us in future research to cross-validate our taxonomy and findings against this independent sample of organizations.

Management ideology versus employee reality. Our reports of HR practice and philosophy were obtained from information provided by founders and top managers. The literature on organizational culture has documented that there is often a large discrepancy between the view of top management and the reality experienced everyday by employees (Martin, 1992), and this may be true in our stridy as well. However, we would make the following points. First, we are interested in understanding what organizational designers were trying to achieve when they created their enterprises and how this shaped what subsequently transpired. Therefore, information on the intentions of founders and top managers is certainly relevant for this purpose. Second, we have documented a strong correspondence between the founder's HR blueprint and the types of HR practices and documencs subsequently adopted by the firm, as well as the speed with which they were adopted. This suggests that the founders' HR models were not merely fanciful rhetoric. Indeed, the mere fact that a top management respondent (e.g. the senior HR manager) reported that his or her firm has adopted some HR practice, such as knowledge-based pay or profit sharing or in-house training, does not speak to the experience that employees have within the organization. Regrettably, it was not feasible for us to sample employees within each of the 172 firms that agreed to participate in the SPEC study. However, we have gathered information on important outcomes, such as personnel turnover and employee lawsuits, which we will examine in future research to cast some light on the employee consequences and perceived legitimacy of HR practices within these organizations.

\footnotetext{
11 Nor were respondens presenced with the cowonomy of business stracegies discused in our compaion paper and subequently asked to clascify themel ves inco cone cucegory; mather, we developed the onxonomy afrer the fect and esigned firms to particular categories based on information obenined from interviems, and, in many crese, from secondary sources (business plans, published articles, etc.).
} 
Survivor bias and sample selection. Finally, some readers of earlier versions of this paper have expressed a concern that despite limiting our sample to nascent organisations, we may nonetheless have obtained a sample of 'survivor organizations that are atypical in some respects that bear on our results or interpretations. We recognize this potential bias; indeed, it was precisely the fact of rampant survivor bias in most studies of HR policies that prompted us to undertake this study in the first place, so we find a certain irony in the criticism. We have attempted to minimize the likelihood of survivor bias in several ways.

First, as noted above in discussing recall bias, we have conducted separate analyses of organizations by age, and we do not find any noticeable differences between organizations that were founded very recently (e.g. in the last four years) versus the rest, as one would expect if the latter group reflected some survivor bias. Second, we deliberately oversampled recently-founded organizations (see Table 1) in an effort to minimize survivor bias. Third, we have augmented the sample of 100 companies analyzed in this paper by gathering data on another 72 firms, again deliberately oversampling recently-created enterprises in order to minimize the extent of survivor bias. By replicating the analyses reported in this paper and in our companion article within that independent sample, we will gain some insight into the extent of any survivor bias plaguing our analyses in these papers. Fourth, the charge of survivor bias would seem to imply that our sample consists of organizations that are relatively stable and that were somehow 'selected for'. In that context, it is interesting to note that of the 100 organizations we studied in the summer of 1994, 7 have already gone out of business or left the Bay Area by May, 1996, and another 14 have either merged with or been acquired by another company since the summer of 1994, suggesting a level of volatility within our sample that does not jibe with the notion that ours is a sample of stable 'survivors'.

Another potential source of bias is the possibility that companies consenting to participate in the first wave of our study are distinctive in ways that colored our findings. Recall that we initially invited 250 companies to participate, of whom 100 consented to do so. We conducted statistical analyses relating the decision to accept or decline our invitation to participate to employment size, age, and industry. We found little evidence of systematic differences between companies that agreed versus declined to participate. Similarly, among companies that participated, we were unable to detect any non-random pattern in the missing data pertaining to HR practice. 


\section{Discussion}

In this paper, we have relied on a unique and rich source of data on early organization-building activities in high technology companies to explore internal consistency within HR systems. Based on information obtained from interviews with founders, we identified four distinct employment blueprints, which we termed the star, engineering, commitment and factory models. These models reflect, in turn, three interrelated dimensions of the employment relationship: the focus of employee artachment and motivation, the basis of selection, and the nature of control and coordination exercised over the labor force.

The strong interrelationships among these three dimensions and the vividness and clarity of the founder models seem consistent with the claim that strong complementarities characterize HR systems. We also found other evidence of consistency and complementarities among HR practices. For instance, we saw that the propensity of firms to adopt specific HR policies and documents and hire a full-time HR manager (and the speed with which they did so, controlling for their employment size and industry) was related systematically to the HR blueprint with which they started. Another interesting datum bearing on the consistency theme is the fact that among the firms in our sample in which family or friends of the founder(s) were listed as key partners in the creation of the company, five-sixths adopted the commitment model, whereas fewer than $30 \%$ of firms overall adopted that blueprint $(\phi<0.001)$ (Burton, 1995). In other words, the active involvement of family members or friends in the founding process resulted in a firm whose employment relationships were structured more along familial lines.

Of course, the most interesting question is whether consistency makes a difference for outcomes that we care about, such as organizational survival and performance, labor force turnover, and the like. Is a high degree of internal consistency at the inception of an organization necessarily a good thing, or does this limit the enterprise's ability subsequently to adapt to a changing environment? The panel aspect of SPEC, which will involve revisiting these firms over time, is intended to allow us eventually to address precisely such questions. Pending such data, one fruitful line of inquiry is to use the retrospective historical data we do have on these companies to examine whether their early evolution is influenced in discernible ways by the strategy and HR model adopted at 'birth'. 'We documented in this paper that the founding HR blueprint does exhibit an enduring effect on the evolution of HR practices and policies. In our companion paper (Hannan a al., 1996), we show not only that the HR blueprints differ in how enduring they are, but that founders' initial strategies and $H R$ models have more far-reaching 
effects, influencing such outcomes as the likelihood of the founder being replaced by a new CEO and of the firm going public. These results all suggest considerable path-dependence in organizational development. Even more interesting for this paper are Burton's (1995) findings that the founder's employment model is a stronger predictor of the firm's current HR practices (in 1994) than is the employment model espoused by the current CEO, which was measured based on 1994 information! ${ }^{12}$ This is yet another indication that organizational origins matter and that the initial premises that guided the design of employment relations exert an enduring effect on these companies, even as they grow, mature, and in some cases change strategies and top management.

Given the possibility of survivor and retrospective recall bias in our sample of organizations (which were selected in 1994 and asked retrospectively about their histories), caution is warranted in drawing strong causal inferences from the data we have analyzed. Nonetheless, we believe the SPEC sample provides richer and more detailed information on early development for a sizeable sample of organizations than any other source of organizational data with which we are familiar. As we follow these firms forward over time and observe their successes and failures, we will be in a better position to assess the implications, if any, of survivor and recall biases on the baseline data gathered from these companies in 1994-1996, which were the basis for the analyses reported in this paper.

In closing, we would note that the empirical approach adopted in this paper, as well as the particular substantive issues addressed, are very much in the spirit of Markets and Hierarcbies (Williamson, 1975). Work organization and employment relationships have been central objects of focus in Williamson's development and elaboration of the TC framework. We have utilized the SPEC data to examine the prevailing conceptions of employment relations among the founders of 100 high tech firms, as well as how those conceptions were implemented and shaped the development of human resource management within their firms.

We believe that research along these lines has some potentially important implications for transaction cost reasoning. For instance, our analyses indicate that founders bring quite different premises and blueprints to the design of employment relations, even founders operating within the same industry. Those blueprints, in turn, shape how human resource systems and organizational structures evolve within their companies. In short, our findings strongly suggest a human resource system 'logic' that guides organiza-

12 Specifically, models incorporating effects of the CSO's HR model did not fe ss well as companble specifications with effects of ehe founder's model. 
tional designers in creating and building their firms, with organizational practices and structures evolving concurrently, as part of an interdependent system, rather than independently. Results reported in our companion paper suggest that these 'logics' change only under great pressure, implying that human resource systems may be characterized by 'punctuated equilibria' or bursts of radical change followed by small, incremental adjustments. Moreover, the apparent costliness and contentiousness of changing employment models should be reflected in increased dissent, turnover, and the like. (It is interesting in this connection to note that in SPEC firms that had changed their HR model, the current CEO was more likely to cite 'organizational and management concerns' and/or 'legal issues' when asked about the major challenges facing the company than were CEOs in firms where the HR model had remained scable). We will be exploring these issues in future research based on this sample of firms.

We also found some preliminary evidence suggesting that the HR models vary in the extent of differentiation in treatment among subgroups of workers, with the star and factory models tolerating, or even encouraging, fairly dramatic distinctions among work roles (and, in some cases, among individuals), while the more familial commitment model is at the other extreme of minimal differentiation. If borne out by future research, these speculations imply that different HR logics entail transaction cost economizing at different levels of aggregation-for instance, in 'star' or 'factory' firms, employment relations may be organized around specific individuals or roles, whereas in 'commitment' firms an overarching model of the employment relation is intended to apply to most or all employees.

We also believe our method-gathering detailed information about a sample of organizations in their formative years, as a baseline for conducting future comparative and longitudinal studies-will eventually prove highly valuable for exploring TCE's predictions regarding the determinants and consequences of how firms structure work and employment. Interestingly, in the final pages of Markets and Hierarcbies; Williamson (1975, p. 263) makes some suggestions for future empirical research on organizational form, market structure, and corporate performance, advocating an approach very similar to what we have done in studying employment practices:

The ambitious approach would involve a reconstruction of the history of the industry [during the-period when dominance of a specific firm emerged], especially during its intermediate stage, for the purpose of assessing default and/or chance event failure. This would require that major eventes be reconstructed and critical decisions made by rivals and prospective entrants be evaluated. 


\section{Acknowledgements}

An earlier version of this paper was presented at the Conference on 'Firms, Markets, and Hierarchies' held at the Haas School of Business, University of California at Berkeley. Authors are listed alphabetically, but authorship is shared equally. The research described in this paper has been generously supported by the Stanford Graduate School of Business, the Stanford Computer Industry Project, and the Alfred P. Sloan Foundation. We wish to thank the research team that has contributed to the SPEC project: Puneet Agarwal, Paola Bonomo, Mollie Brown, Angela Celio, Mamie Hsien, David Lam, Peter Mendel, Megan Miller, Tang-Nah Ng, Ed O'Hara, Jennifer Sellars, Eric Smith, Srija Srinivasan, Srikanth Srinivasan, and Tari Vickery.

\section{References}

Barnetr, W. P. and G. R. Carroll (1995), 'Modeling Incernal Organizacional Change,' Amamal Revime of Seciolog, 21, 217-236.

Baron, J. N., A. Davis-Blake and W. T. Bielby (1986), The Seructure of Opportunity: How Promotion Ladders Vary Within and Among Organizations, Adminissrative Scima Qmatedy, 31, 248-273.

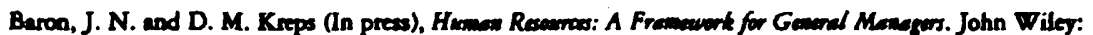
New York.

Baron, J. N. and J. Pfeffer (1994), The Social Paychology of Organizations and Inequalizy. Sacid Psycbalsov Quverly, 37, $190-209$.

Burton, M. D. (1995), The Evolution of Employment Systems in High Technology Firms,' unpublished PhD disertation. Departinent of Sociology, Stanford Univenity.

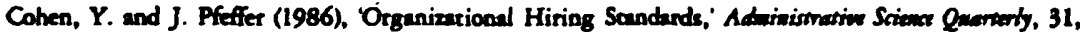
$1-24$.

Prank, R. H. (1988), Passiens witbio Reasew. Norton: New York.

Hennan, M. T., M. D. Burton and J. N. Baron (1996). 'Inertia and Change in che Early Years: Employ-

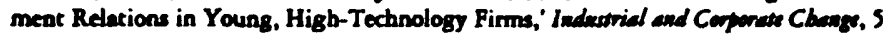

Hennan, M. T. and J. Freeman (1977), The Population Ecology of Organizations; Anvicen Jewind of Secielny, 82, 929-964.

Henman, M. T. and J. Freeman (1984), 'Seructural Inertia and Organizational Change, A marican Sarialegical Revinu, 49, 149-164.

Ichniowndi, C., K. Shav and G. Prennuhi (1993), The Effects of Human Resource Practices on Productivity,' unpublished manuscript, School of Business, Columbia University.

Kreps, D. M. (1996), 'Markes and Hienurchies and Mathemacical) Economic Theory,' Indurtrial and Coppenase Cbores, 5

MecDuffie, J. P. (1995), 'Human Resource Bundles and Mnnufacturing Performance: Organizational Logic and Flexible Production Syseems in the World Auto Indusery; Industrial and Law Relations Rovine, 48(2), 197-221.

MacGregor, D. (1960), Th Hewen Sidk of Entrive. MoGraw-Hill: New York.

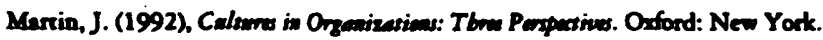

Milgrom, P. and J. D. Roberts (1995), 'Complementerities and Fir: Scranegy, Scructure, and Organizationd Change in Menufacturing," Jannal of Amowing and Eownio, 19, 179-208.

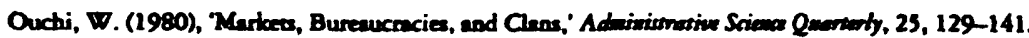




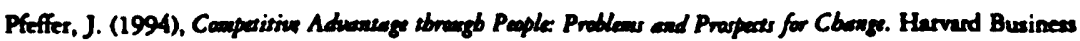
School Press: Boston, MA.

Pfeffer, J. and Y. Cohen (1984), 'Determinanes of Internal Labor Marteets in Otganizations,' Adminisma-

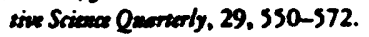

Rohwer, Gortz (1994), Treasision Dete Amalysis (TDA), Version 5.7.

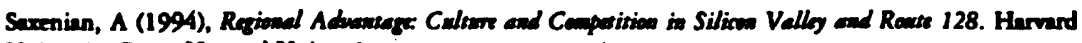
Uajversity Preas: Harvand University.

Simon, H. A. (1951), 'A Formal Theory of the Employment Relecionehip,' Ecomemerrice, 19, 293-305.

Tuma, N. B. and M. T. Hennen (1984), Social Dyacuia. Academic: Orhendo, FL.

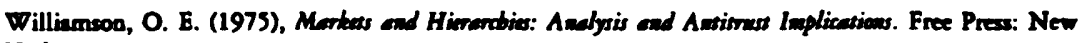
York.

Williameon, O. E. (1981), The Economica of Otganization: The Transaction Coer Approach, Americas Jowrinal of Siciology, 87, 548-577.

Williameon, O. E. (1992), Transection Cose Economics and Organization Theory: unpublished manuscripe, Hess School of Business, Univensity of Califomis, Betkeley. 